\title{
Using teacher inquiry to support technology enhanced formative assessment: a review of the literature to inform a new method
}

\author{
Luckin, R., Clark, W., Avramides, K., Hunter, J. \& Oliver, M. Interactive Learning \\ Environments, 1-13 15 Jan 2016. DOI:10.1080/10494820.2015.1121152
}

\begin{abstract}
In this paper we review the literature on Teacher Inquiry to explore the possibility that this process can equip teachers to investigate students' learning as a step towards the process of formative assessment. We draw a distinction between formative assessment and summative forms of assessment (CRELL, 2009, Webb, 2010, EACEA, 2009, OECD, 2010b). Our review of Teacher Inquiry is combined with a review of the research concerning the way that practices with technology can support the assessment process. We conclude with a comparison of Teacher Inquiry and Teacher Design Research from which we extract the characteristics for a method of teacher inquiry that can be used to develop technology enhanced formative assessment: Teacher Inquiry into Student Learning (TISL). In this review our primary focus is upon enabling teachers to use technology effectively to inquire about their students' learning progress.
\end{abstract}

Keywords: Formative Assessment; Teacher Inquiry; Technology Enhanced Learning; Design Research; Learning

\section{Introduction}

There is an increasing expectation that teachers will use technology to assess their students' learning (Johnson et al, 2014; DfE, 2010). This expectation is partly fuelled by the investment that schools have made in technology (Becta, 2010) and partly by the pressures of comparative league tables and evaluations, and the increase in teacher accountability (DfE, 2010).

Our focus in this paper is on how teachers can address these expectations through the process of Teacher Inquiry with technology. We review the literature on Teacher Inquiry and on the use of technology to support the assessment process. The review is divided into three sections: the first provides a context for the review through an initial discussion of the current state of the art in policy and practice around assessment in schools nationally and within Europe more generally. The second section reviews the literature concerning the process of Teacher Inquiry (TI) and the final section explores the assessment practices with technology that are currently the focus of research attention.

The paper concludes with a comparative overview of Teacher Inquiry and Teacher Design Research through which we identify the key characteristics for Teacher Inquiry that need to be harnessed to drive the technology enhanced formative assessment process.

\section{The Policy and Practice Context}

Within Europe there are increasing expectations about teachers' abilities and autonomy, including in the assessment of learning. In its recent white paper on "The Importance of Teaching", the UK government outlines its plans for a comprehensive review of the English education system. At the heart of this review lie concerns with the standing (potential or actual) of the English education system compared to its international counterparts (DfE, 2010, EACEA, 2009, OECD, 2010b). There is a move towards decentralised control and increased teacher and school autonomy coupled with greater 
accountability of schools at the local or community level. Teacher quality is intended to be improved through the increased localisation of training, professional development opportunities and school improvement; and harnessing detailed performance data for assessment and ease of comparison of school effectiveness in specific areas. These policies advocate that schools should be accountable for the progress that children make, and information about this should be publicly available (DfE, 2010).

More broadly the 2009 report on national testing across Europe (EACEA, 2009) characterizes pupil assessment as complex and involving a variety of assessment instruments and methods, both formative and summative; it also notes that the assessment process is integral to the overall structure of educational systems. The report identifies three key purposes for assessment in schools:

* Formative (assessment for learning): focusing on the day-to-day learning needs of individual pupils and adapting teaching accordingly

* Summative (assessment of learning): summarising the achievement of individual pupils at the end of a school year or key stage

* Evaluative (assessment of education quality): used as an indicator of individual school/teacher performance in terms of education quality and the effective application of policies and practice

Whilst highlighting the role of national and summative assessment in relation to teacher quality and school improvement, the report emphasizes that the form of assessment most commonly used is continuous assessment: the ongoing monitoring and tracking of students' learning progress.

These perspectives on international benchmarking and increased teacher autonomy in the school setting do, however, have implications for teachers' professional practice. The 2008 EC report (Eurydice, 2008) which examined levels of teacher autonomy and responsibility across Europe found, for example, that whilst increased levels of autonomy allowed teachers greater flexibility of action, this was coupled with increased responsibility for outcomes. Elements considered important for comparing the relationship between increased autonomy and accountability included, the political context, the Educational system (curriculum, teaching methods, pupil assessment), teacher time and required duties, and teacher participation in educational reforms and innovations.

In parallel with these developments in what is expected of teachers, there have been developments in what should be expected of learners in today's society, which is characterised by globalisation and rapid change. There is a new emphasis on the acquisition of what are often referred to as " 21 st century skills" (Kozma, 2009). These skills include critical thinking, problem solving, communication, collaboration, creativity and innovation, alongside reshaped notions of learning as a lifelong and lifewide activity (P21-Skills, 2007) supported by ICT use and requiring effective digital literacy. The adoption and negotiation of these skills suggests a need to review the ways in which students' learning is assessed. It also suggests the need for an increased understanding of how this developing assessment landscape might contribute to adaptive teaching and learning approaches in the classroom and beyond (Honey et al., 2005). A 2009 report, drawing on a collaborative project on 21 st century skills and assessment that involved Cisco, Intel and Microsoft as well as the OECD, PISA and academic researchers, argued that:

"Existing models of assessment are typically at odds with the high-level skills, knowledge, attitudes and characteristics of self-directed and collaborative learning 
that are increasingly important for our global economy and fast changing world. New assessments are needed that engage students in the use of technology and digital resources and the application of a deep understanding of subject knowledge to solve complex, real world tasks and create new ideas, content, and knowledge."

(Kozma, 2009)

In parallel to the increased pressure for teachers to interpret and appraise large amounts of data about students' learning (Johnson et al, 2014; DfE, 2010; OECD, 2005), the last decade has seen schools across Europe increasing their investment in the adoption and use of technology for teaching and learning. This has been accompanied by rising expectations for more effective teaching and learning and, in particular, the assessment of students' learning (Becta, 2008, 2009, 2010; EVA, 2009). However, whilst technology has done much to support the more routinised aspects of record-keeping, monitoring and assessment, and has begun to offer capacity for data-sharing between teachers, parents, learners and other stakeholders, this capacity and the richer, more formative aspects of students' Technology Enhanced Learning (TEL) data have remained difficult to operationalise, capture and evaluate (Pedró, 2010, OECD, 2010a). The increasing use of web 2.0 tools by learners (Luckin et al., 2008, Elliott, 2007) and, in some countries, the increased student/teacher access to online learning environments (Jewitt et al., 2010, CDD, 2010) and one-to-one computing (Balanskat and Garoia, 2010) points to a need for new and extended perspectives on technology-enhanced assessment in the school setting. There is a need to identify and evaluate how and to what extent the availability and use of advanced learning technologies can contribute to teachers' learning about students' learning and enhanced assessment literacies at the school level. Developments in technology-enhanced teaching and learning, such as the introduction of virtual learning environments, networked society, mobile and ubiquitous computing, augmented reality and improvements in AI-enabled technologies have produced a situation in which schools are, increasingly, technically complex sites of learning in a digital society. Progress has been made amongst teachers and learners in the development of the skills and competencies required to use ICTs productively (Grunwald Associates, 2007), but progress in the areas of assessment practices continue to lag behind (EVA, 2009, Webb, 2010, Balanskat et al., 2006)

\section{Teacher inquiry as a means of developing practices}

Teacher Inquiry (TI) is an approach to applied research that begins to appear in the late 1980s (Cochran-Smith and Lytle, 1999), and which focuses on the ability of teachers to develop evidence-based insights into their own professional practice. However its origins can be found in much earlier work, such as that of Dewey, who as early as 1933 was already expounding the benefits of teachers' reflective practice (Rich and Hannafin, 2008). Others have described the Teacher Inquiry approach as having its origins in action research, critical inquiry and teacher research (Lytle and Cochran-Smith, 1994). Ritchie (2006) attributes an insider's perspective to Teacher Inquiry, aligning the approach to teachers conducting their own research, in real classrooms and school settings, and focusing on local issues, which may or may not be generalisable to wider contexts. Dana \& Yendol-Hoppey (2009), meanwhile, describe Teacher Inquiry as a vehicle for teachers, whereby not only are they enabled to "unravel the complexity of the profession" but also to "raise the teachers' voice in discussions of educational reform". O'Connell Rust (2009), however, marks Teacher Inquiry as a challenge to the academy because the insider focus 
and the manner in which questions are posed and data are collected, analysed and evaluated raises questions for traditional notions about validity, objectivity and reliability.

The key characteristics of Teacher Inquiry can be summarized as reflecting:

- an action-oriented approach;

- an insider view;

- localised reflection;

- the empowering of teacher voice;

- a challenge to traditional academic practices that have engendered a debate around its validity as a research approach.

These characteristics, issues and debates are further explored by Dana \& Yendol-Hoppey (2009) who argue that an "outsider" perspective has tended to dominate school-based research. Teacher Inquiry can bring an "insider" perspective, which may offer valuable and potentially more meaningful insights than that limited by the traditions of knowledgebuilding as defined by the academy. The Teacher Inquiry method promotes a bottom-up, teacher-centred approach to research more akin to participatory design research methods (Shurville et al., 2007, Lewin and Luckin, 2010, Underwood et al., 2009).

For the purposes of this review we define Teacher Inquiry as: teachers' systematic research of their own practice in context in order to improve teaching and learning (Rich and Hannafin, 2008).

This process offers a bridge between research, practice and education policy, to engage teachers as consumers of research and as designers of their own professional development (O'Connell Rust, 2009) in an intentional, self-critical process of self inquiry (CochranSmith and Lytle, 1999). Teacher Inquiry as an approach to research can be characterised by a number of common features around identifying, framing, planning and enacting an inquiry into teaching practice. In line with its definition as systemic, intentional and contextual, the approach generally takes a definite, planned, purposeful and action-oriented stance.

The literature suggests that the formulation of an initial question is key to the teacher inquiry process (O'Connell Rust, 2009). It is a perplexity (Dewey, 1933), a burning question or passion (Dawson, 2006), a wondering (Dana and Yendol-Hoppey, 2009), it is relevant inquiry (Borst, 1999 cit. in Dana et al., 2001) and it is often specific to the teacher's everyday, moment-to-moment activity and actions (Rich and Hannafin, 2008). If this formulation of a question is one that reflects a focus upon the process of inquiring about how students' learning is progressing, then it may have an important contribution to make to our understanding about how best to help teachers conduct the assessment process. If the inquiry process is one that uses the vast resources provided through the use of technology in the teaching and learning process, then it may also add considerable depth to our efforts to help both teachers and learners to use technology in their approach to the formative assessment process of learning.

The benefits of Teacher Inquiry include, for example, the manner in which teachers become collaborators in educational research by investigating their own teaching and learning problems, a process that can make them more likely to facilitate change based on the knowledge they themselves create. It can provide the impetus for teachers to find solutions to their own questions and creates an inquiry stance towards teaching that can lead to meaningful change for students (Dana and Yendol-Hoppey, 2009). Ellis and Castle 
(2010) further state that the agency of Teacher Inquiry generates a confidence in the self that allows for persistence in the face of obstacles. It encourages teachers to adopt a sense of personal responsibility that results in an ability to make professional decisions and engage in inquiry, thereby becoming capable of improving their own teaching and schooling for the benefit of their students and community. Zeichner (2003), likewise, sees Teacher Inquiry as an important means of professional development and educational change. These benefits are increasingly relevant as the emphasis upon teacher autonomy grows and as the technology and data that teachers are required to use becomes increasingly complex.

There are also limitations to Teacher Inquiry and it is important and useful to identify and recognize some of these limitations as we consider Teacher Inquiry as a method to support the use of advanced technologies for the purposes of formative assessment. Concerns have been raised about the research rigour and validity of the evidence base created through the Teacher Inquiry Process (O'Connell Rust, 2009); the adequacy of appropriate training for teachers and their orientation to tools and methods (Dawson, 2007, Rich and Hannafin, 2008); the available support for teachers' professional growth at school and policy level (Hendricks, 2009, Dana et al., 2001, Ellis and Castle, 2010); the potentially low levels of generalisability of results (Barab et al., 2003); the lack of motivation and time, and the impact of teachers' existing workloads (Rich and Hannafin, 2008)

O'Connell Rust (2009) suggests that because Teacher Inquiry is "intimately embedded in practice and in the time-frames of teachers' lives in classrooms" teachers have a readily available body of evidence that could be brought into this process, including: "classroom maps, anecdotal records, time-sampled observations, samples of student work, drawings and photographs, audio and video recordings, interviews, conversations, surveys, and teacher's journals, which can be used, over time, to answer questions about practice."

\section{$\underline{\text { Teacher Design Research }}$}

Before considering examples of technology being used to support assessment, it is worthwhile contrasting Teacher Inquiry with another method through which teachers are actively involved in developing their practice. Teacher Design Research (TDR) is a particular approach to participatory design that focuses on developing teachers' expertise as adaptive innovators through long-term involvement in iterative design research and a process of guided professional development (Bannan-Ritland, 2008, p. 246). A key feature of this approach is that teachers' learning comes from their own experiences of cognitive dissonance during the design cycle rather than from outside experts per se. Teachers learn about design processes as research activity, whilst researchers learn about teaching practices as design principles, each learning from the other. In this way, Bannan-Ritland suggests:

Teacher design research then becomes a context for inquiry that meaningfully provokes teachers to restructure their core ideas, beliefs, and practices. (BannanRitland, 2008, p. 246)

This, in turn, has been described by some as a means of re-envisioning teachers' professional development needs by enabling teachers to move beyond existing routines to reconceptualise their practice in a process of context-oriented continuous innovation which allows teachers to construct their own meanings of change processes, both individually and 
collectively (e.g. Laurillard, 2012). From this perspective, problem definition begins with teachers rather than researchers and the design process encourages the articulation, through dialogue, of teacher beliefs and practices in the form of a shared community of inquiry. A key characteristic of this approach is that:

Teachers are treated as design researchers actively involved in contributing to a conceptual design, and the power of the context of their classrooms is recognized as fundamental to design and research activities. (Bannan-Ritland, 2008, p. 249)

As such, Teacher Design Research, as a participatory design model, places the teacher (and their students, classrooms and schools) at the heart of the educational research process. A key goal of this approach is to realign teachers' professional development with their own context and practices and to expand the outcomes of this model to include national and international levels. One successful and much adopted example of the TDR approach is the Japanese Lesson Study model ${ }^{1}$, the premise of which is that a small group of educators jointly designs, teaches, studies and refines a single class lesson. This takes the form of a 'research' lesson with a view to improving teaching and learning and teachers' pedagogical knowledge (Cerbin and Kopp, 2006) in and through their enactment of an iterative, emergent and cyclical design process.

Teacher Design Research as a method involves rethinking traditional ideas about how educational research is conducted. Researchers must be prepared to devolve power to participants, and participants must be open to new ideas and be intimately involved in creating and sharing those ideas (Bannan-Ritland, 2008, p. 259). Some hope that this will help to close the "credibility gap" (Levin \& O'Donnell, 1999) in educational research, which is often seen to be too far detached from practice to be useful from a teacher's perspective (The Design-Based Research Collective, 2003, p. 5).

\section{Linking Teacher Inquiry and Teacher Design Research}

The first section of this review highlighted the expectations that the current educational context places on teachers to be effective in and accountable for their assessment of student learning. The next reviewed the literature on the practice of Teacher Inquiry more generally. We now explore the relationship between these, and in particular, work in which teachers use technology specifically to inquire into and assess their students' learning.

Teacher Inquiry has been applied to many areas of teaching and learning over the last three decades, covering a range of subject areas and teacher-oriented practices. However, its use in curriculum-based, technology-enhanced field experiences is not common practice (Dana and Dawson, 2007). Daly et al., (2009), in their study of teachers continuing professional development with ICT, argue from a technology perspective that: "teachers need to use social software such as blogging and podcasting to support inquiry into their practice" and that "teachers need to learn how to work with Web 2.0 and integrate technologies into their everyday lives". This recognition of the need for better engagement with emerging technology is also evidenced in a recent OECD report on students' technology use and its impact on educational performance as evidenced in PISA (Pedró, 2009). The report raises concerns about the potential lack of awareness among educators, parents and policy makers about the consequences of the increasing ICT familiarity of students and of a second digital divide around competences and skills in ICT

\footnotetext{
1 http://www.lessonresearch.net/
} 
use. It calls for the fostering and development of 21 st Century skills and competences amongst students and the adoption of holistic policy approaches to ICT in education as computer ratios reduce and the availability of digital learning resources grows.

Here we present a comparative review of three case studies. These represent teacher inquiry in a range of contexts, beginning with peer-led continuing professional development; then moving to structured professional development; and finally to structured and assessed development. Whilst these are all US-based cases, and therefore may not be representative of the whole field of teacher development or inquiry, they offer strong examples of the variety of links possible between development and inquiry. We use these examples to identify a set of common characteristics, which may usefully contribute to the development of a framework for technology-supported teacher inquiry into students' learning.

Study 1 explores the participatory design of an online community of practice in the form of an inquiry learning forum (Barab et al., 2003),

Study 2 examines a study of pre-service teachers' mentor-supported inquiry into the use of technologies as a support for teaching and learning in field experiences [school placements] (Dawson, 2007).

Study 3 focuses on the use of a video analysis tool to support Teacher Inquiry into students' learning in pre-service teachers' mentor-supported field experiences [school placements] through the lens of national assessment standards (Rich and Hannafin, 2008).

The comparative review of these cases is provided below in the form of a matrix. In this matrix (Table 1), common themes across the three studies have been identified (column 1) with the aim of providing a baseline typology for the consideration of the kinds of tools and methods that may potentially be of interest in a Teacher Inquiry scenario.

\section{TABLE 1 HERE}




\section{Findings from the cross-case review}

The results of this cross-case review suggest that the following are important characteristics to be considered in planning a teacher inquiry type scenario.

- A clear understanding of the inter-relationships between teachers, researchers and designers; acknowledging the potential impact of crossing boundaries between insider and outside knowledge; and identifying ways of negotiating differences in understanding, purposes and goals

- Recognition of the mutual inter-relationships between study (teacher-led activity) and meta-study (researcher-led activity) in the development and application of inquiry methods and tools

- Recognition of the need, and planning for, participant orientation to tools and/or methods

- Recognition of the implications of teacher agency and finding a balance between teachers' application of the inquiry process and the co-development of this process by teachers, researchers and tool designers

- Understanding the difference between the provision of tools to support inquiry (in general) as in study 1; and the provision of a set of tools and methods for designing teacher inquiry, as in studies 2 and 3

The cross-case comparison of studies into the Teacher Inquiry process examined above show that there is a precedent for dialogue between researcher-led and teacher-led development and the application of Teacher Inquiry methods.

These three studies also illustrate a shift, over time, in emphasis away from researcher-centred studies to teacher-centred approaches. This is in line with the general literature on Teacher Inquiry discussed earlier in this review. At the same time, it is evident that this shift has been accompanied by a move towards a more design-centred approach to Teacher Inquiry and the generation of inquiry methods that will support and guide teachers and enable them to participate in evidence-centred and evidence-based decision-making (see studies 2 and 3 in particular). This systematisation of the Teacher Inquiry process is intended to go some way towards bridging the gap between classroom and academy and to meeting concerns raised in the literature around the validity of teacher research (O'Connell Rust, 2009).

\section{Teacher Inquiry into assessment practices with technology}

Research on technology and assessment provides evidence that researchers and teachers are rising to the challenge, but there is considerable work still to be done. Attention has often focused on summative testing (SQA, 2007, Beevers, 2010). However, recent trends and developments in technology (Winkley, 2010), such as mobile, ubiquitous, distributed and immersive environments, as well as a rise in social and collaborative networks have generated an increasing interest in the use of technology as a support for formative assessment (Beevers, 2010, Elliot, 2007, Pachler et al., 2009). Whilst the latter encompasses the more routinised aspects of record-keeping, monitoring, 
assessing and reporting on the learner's progress, it also extends to an increased capacity for data capture, analysis and dissemination. Examples include the use of e-voting systems (Hanley and Jackson, 2006), learner e-portfolios (Kimbell, 2008), diagnostic testing environments which offer adaptive, ipsative assessment data for teachers and students over time (Winkley, 2010, Ripley, 2007, Bull and Kay, 2007, Zapata-Rivera et al., 2007), use of handheld devices to capture data (Bennett and Cunningham, 2009), activity logs, timestamps, version tracking, target-setting (Jewitt et al., 2010), self-guided learning (Sainsbury, 2009), learning journals, and so on. Less well developed, but increasingly emergent, are new forms of assessment, which take into account opportunities for technology-supported peer, collaborative, and self-guided learning (for both teachers and learners) using online social networks and read-write technologies such as web 2.0, (Luckin et al., 2008, Elliott, 2007) as well as for increased parental participation (Lewin and Luckin, 2010) via distributed learning networks. While routine and simple adaptive testing in well-defined domains is now easier, at least, where established question banks exist, there remain concerns about authenticity and plagiarism.

In parallel to the increased interest in formative assessment and the use of technology, the nature of the technology that can be used to support assessment is continually developing. This constant state of flux means that the practices through which technology is used for assessment are also evolving. One current technology development with specific implications for assessment is Learning Analytics (Nesta, 2012). Learning analytics (LA) is concerned with interpreting the wide range of data available about learners and presenting the results of this interpretation in ways that can be used to assist the learning processes. This represents a major step towards using technology to measure what matters for learning, rather than what is simply easy to measure. LA involves the tailoring of educational opportunities based on advances in modelling learners by collecting data, the use of data mining techniques, and the visualisation of data as appropriate to learners, teachers and others [see http://horizon.wiki.nmc.org/Learning+Analytics]. Frequently, the data that is gathered about learners is derived from learners' online interactions. However, smaller numbers of tools exist that gather data from other sources, such as galvanic skin responses, heart rate and learners' own self-reports (Luckin, 2010). LA draws heavily on advances made in the field of educational data mining, which draws on other disciplines such as data mining, psychometrics and statistics, and on visual methods for data analysis. LA offers a strong example of how technology offers unique opportunities for assessment. However, the potential of these opportunities to be met will depend greatly on teachers' ability to structure effective inquiry activities to probe the rich data sets that technology can afford. Technology can support assessment for learning by providing tools to traffic in assessment interactions: potentially making them more prompt, representationally rich, and interactive, but only if teachers become fluent in using the available technological tools to inquire about their students' learning.

The technology enhanced assessment literature primarily focuses upon learning in a formal classroom or laboratory environment and the subject of the assessment is typically a formal subject area, such as science, including computer science (Nesta, 2012). There are examples of work that considers less formal environments: Wishart et al. (2010), for example, report work in a museum context where teachers and peers provided feedback and guidance to student groups as they constructed presentations. Other work focuses upon automated assessment techniques. For example, Naudé et al., (2010) report the use of an automated assessment technique (AssignSim) that quantifies the structural similarity between unmarked student submissions and marked solutions. The reported experiments show a good correlation of assigned marks with that of a human marker. The range of 
technologies that are used also varies. For example, a Web-based dynamic assessment tool is discussed by Wang et al (2010) and is demonstrated to provide e-Learning effectiveness over a 2-week period as evaluated by post-test scores, whilst an interesting example of Audio Feedback Assisted Learning for Student and Staff Experience (AFAL), found positive impact on learning when optimal methods of audio feedback were employed (JISC 2010).

There are many examples of innovative and well researched e-assessment techniques being used within Higher Education, but little evidence of any substantial and positive impact on learning and teaching (JISC, 2009). Cultural and administrative practices can 'mitigate against the propagation of successful initiatives' (ibid: 14).

Our review has identified some interesting examples of technology being used to support the processes of teacher inquiry and formative assessment. These examples highlight the wide variety of technologies and practices that are being adopted. They also highlight the impact of the culture and context within which the technology is being used. Various contextual factors were identified as constraining the innovations being reported, for example, difficulties in accessing resources, such as appropriate physical location, technology devices or human support. Institutional rules (home and formal educational institution), regulations, curricular, timetabling and the entrenched nature of learners' existing habits and their prior, informal experiences were also identified as limiting factors.

The institutional, practice-based character of these limiting factors suggests that the Teacher Inquiry process is well placed to understand and intervene in the broader context within which teachers operate. It may therefore offer a useful medium for the introduction of technology innovation. In the final section of this paper we outline a proposed methodology through which Teacher Inquiry can be used to assist the development of effective technology enhanced assessment.

\section{Discussion: teacher inquiry into student learning}

Against the context described earlier, and faced with the complexity of the so-called "wired society", the use of Teacher Inquiry (TI) to support teachers' technology-supported evaluation of students' learning offers an important opportunity for shaping teachers' participation from the bottom-up. In this review we couch the process of assessment as a process through which teachers inquire about their students' learning progress. We situate this within the broader sphere of Teacher Inquiry more generally.

Table 2 provides a comparative overview of the key features of Teacher Inquiry, and Teacher Design Research drawn from the review of the literature. We have selected Teacher Inquiry and Teacher Design Research specifically, because they are popular processes through which teachers are able to involve themselves in the research process. Alongside these, we present a preliminary outline of the characteristics that are important to the implementation of Teacher Inquiry. When applied to the assessment process we have called this integration of Inquiry and Design Research, "Teacher Inquiry into Student Learning" (TISL). We propose that these TISL characteristics are used to frame a method. The table makes clear that TISL benefits from earlier work around the process of teacher inquiry and its contribution to teacher professional development and the wider research, educational and policy communities. There are some key ways in which TISL extends and builds on this prior art, as follows:

- An increased emphasis on data-driven decision-making

- A sharp focus on the impact, role and implications of technology and the implications of technology for data capture, analysis and visualisation 
- A focus on real-time adaptations in teaching and learning

- A focused view of teacher professional development centred on the development of teachers' assessment literacy, and of technology-supported formative e-assessment in particular. Freebody et al. (2006) suggest that, in the kinds of rapidly changing contexts facing schools today, the notion of teachers as innovators is crucial to successful change management in schools.

- A holistic, systemic approach to teacher professionalism which integrates deeply both with students' learning and with schools' wider strategic planning needs (through the lens of assessment practices and purposes)

Teachers need to be able to create and adapt their instructional practices, to use robust methods of systematic inquiry, to engage in knowledge-building dialogues with professional instructional designers and university researchers, and to contribute to advances in their specialist knowledge domains. In other words, teachers need to work as innovators who design and create new pedagogical practices, as researchers who inquire into and assess their innovations, and as knowledge builders who contribute to accumulating the knowledge of their professional community (Freebody et al., 2006, p 65). Schools should see themselves as innovation networks (Hargreaves, 2008). In order for this to happen, teachers need to be encouraged and supported in their engagement in a systematic inquiry into their own practices, thus enabling schools to capture and benefit from the emergent innovations that arise in and through the everyday practice of teachers as they respond to specific issues arising in the local context (ibid, p67).

\section{TABLE 2 HERE}

In this paper we have reviewed the literature concerning the process of Teacher Inquiry and the practices through which teachers conduct assessment activities with technology. We identify the situation in which schools are increasingly technically complex sites of learning in a digital society and recognize that progress in the areas of assessment practices continue to lag behind technology enhanced learning more generally. We conclude by identifying a set of key characteristics of Teacher Inquiry that are used to formulate the TISL characteristics, which can be used as the basis for a method to support the formative assessment process using technology.

\section{References}

Balanskat, A. \& Garoia, V. 2010. Netbooks on the rise: European overview of national laptop and netbook initiatives in schools. Brussels: European Schoolnet.

Balanskat, A., Blamire, R. \& Kefala, S. 2006. The ICT Impact Report: A review of studies of ICT impact on schools in Europe. In: SCHOOLNET, E. (ed.). European Commission.

Bannan-Ritland, B. 2008. Teacher design research: An emerging paradigm for teachers' professional development. Handbook of design research methods in education: Innovations in science, technology, engineering, and mathematics learning and teaching. New York: Routledge.

Barab, S. A., Makinster, J. G. \& Scheckler, R. 2003. Designing System Dualities: Characterizing a Web-Supported Professional Development Community. The Information Society, 19, 237-256. 
BECTA (2008), Harnessing Technology Review 2008, 2009: The role of technology and its impact on education. Coventry: Becta.

Beevers, C. 2010. What can e-assessment do for Learning and Teaching? Edinburgh: The E-Assessment Association (eAA).

Bennett, K. R. \& Cunningham, A. C. 2009. Teaching Formative Assessment Strategies to Preservice Teachers: Exploring the Use of Handheld Computing to Facilitate the Action Research Process. Journal of Computing in Teacher Education, 25, 99-105.

Bull, S. \& Kay, J. 2007. Student Models that Invite the Learner In: The SMILI:() Open Learner Modelling Framework. International Journal of Artificial Intelligence in Education, 17, 89-120.

Bull, S. \& McKay, M. An open learner model for children and teachers: inspecting knowledge level of individuals and peers. 2004. Springer, 232-251.

CDD 2010. Virtual Learning Platforms in Europe:What can we learn from experience in Denmark, the United Kingdom and Spain? Paris: Caisse des Dépôts.

Cerbin, W., \& Kopp, B. (2006). Lesson study as a model for building pedagogical knowledge and improving teaching. International Journal of Teaching and Learning in Higher Education, 18 (3) 250-257.

Chi, C., Zhou, M.X., Yang, M., Xiao, W., Yu, Y., \& Sun, X. (2010) Dandelion: supporting coordinated, collaborative authoring in Wikis. In E. Mynatt, G. Fitzpatrick, S.

Hudson, K. Edwards, \& T. Rodden (Eds.) CHI '10: Proceedings of the 28th international conference on Human factors in computing systems, Atlanta, GA, USA, April 10-15, 2010 (pp. 1199-1202). New York, NY: ACM Press.

Cochran-Smith, M. \& Lytle, S. 1999. The teacher research movement: A decade later. Educational Researcher, 28, 15-25.

Crell 2009. The Transition to Computer-Based Assessment: New Approaches to Skills Assessment and Implications for Large-scale Testing. In: SCHEUERMANN, F. \& BJÖRNSSON, J. (eds.) JRC Scientific and Technical Reports. Ispra (VA), Italy: CRELL.

Daly, C., Pachler, N. \& Pelletier, C. 2009. Continuing Professional Development in ICT for Teachers: A literature review. Coventry: Becta.

Dana, N. F. \& Dawson, K. 2007. When curriculum-based, technology-enhanced field experiences and teacher inquiry coalesce: An opportunity for conceptual change? British Journal of Educational Technology, 38, 656-667.

Dana, N. F. \& Yendol-Hoppey, D. 2009. The reflective educator's guide to classroom research: learning to teach and teaching to learn through practitioner inquiry, Thousand Oaks: CA, Corwin Press.

Dana, N. F., Gimbert, B. \& Yendol-Silva, D. 2001. Teacher Inquiry as Professional Development for the 21st Century in the United States. Change: Transformations in Education, 4, 51-59.

Dawson, K. 2006. Teacher Inquiry: A Vehicle to Merge Prospective Teachers' Experience And Reflection during Curriculum-Based, Technology-Enhanced Field Experiences. Journal of Research on Technology in Education, 38, 265-292.

Dawson, K. 2007. The Role of Teacher Inquiry in Helping Prospective Teachers Untangle the Complexities of Technology Use in Classrooms. Journal of Computing in Teacher Education, 24, 5-12.

Dewey, J. 1933. How we think: A restatement of the relation of reflective thinking to the educative process, New York, NY, D C Heath \& Company.

DFE 2010. The Importance of Teaching: The Schools White Paper 2010. HMSO. 
EACEA 2009. National Testing of Pupils in Europe: Objectives, Organisation and Use of Results. Brussels: Eurydice.

Elliott, B. 2007. Assessment in the age of Web 2.0. Glasgow: Scottish Qualifications Authority.

Ellis, C. \& Castle, K. 2010. Teacher research as continuous process improvement. Quality Assurance in Education, 18, 271-285.

Eurydice 2008. Levels of Autonomy and Responsibilities of Teachers in Europe. Brussels: Eurydice, Education and Culture DG.

EVA 2009. The Use of ICT in Danish Schools. A study of experience and perspectives English Summary. Copenhagen: Danish Evaluation Institute.

Freebody, P., Reimann, P. and Tiu, A. (2008) Alignment of perceptions about the uses of ICT in Australian and New Zealand Schools. University of Sydney.

FutureLab (2010) 'New Assessment Scenarios' Report. December, 2010. Available from: http://www. futurelab.org.uk/sites/default/files/New_assessment_scenarios.pdf

Grunwold Associates, L. 2007. Creating and Connecting//Research and Guidelines on Social - and Educational - Networking. National School Boards Association.

Hanley, J. \& Jackson, P. 2006. Making it click. Technology \& Learning, 26, 11-34.

Hargreaves, David H. (2008). Leading System Redesign - 4: Innovation Networks in Action. London: Specialist Schools and Academies Trust.

Hendricks, C. 2009. Improving Schools through Action Research, Columbus, OH, Pearson.

Honey, M., Fasca, C., Gersick, A., Mandinach, E. \& Sinha, S. 2005. Assessment of 21st century skills: the current landscape New York: NY: Partnership for 21st Century Skills and Education Development Center's Center for Children \& Technology.

Jewitt, C., Hadjithoma-Garstka, C., Clark, W., Banaji, S. \& Selwyn, N. 2010. School use of learning platforms and associated technologies. Coventry: Becta.

JISC (2009) Final Report Ridgway (Project Team Member), Robert Harding (QA), Hakan Redif (Project Manager) March 2009 Filename RAeAT Final Report General project information and a list of e-Assessment projects listed on: http://www.dur.ac.uk/smart.centre1/aeac

JISC (2010a) Available at: http://www.jisc.ac.uk/whatwedo/programmes/elearning/

JISC (2010b) Available at: http://www.jisc.ac.uk/whatwedo/programmes/elearning/ltig/afal.aspx.

JISC Final Report Ridgway (Project Team Member), Robert Harding (QA), Hakan Redif (Project Manager) March 2009 Filename RAeAT Final Report General project information and a list of e-Assessment projects listed on: http://www.dur.ac.uk/smart.centre1/aeac

Johnson, L., Adams Becker, S., Estrada, V., Freeman, A., Kampylis, P., Vuorikari, R., and Punie, Y. (2014). Horizon Report Europe: 2014 Schools Edition. Luxembourg: Publications Office of the European Union, \& Austin, Texas: The New Media Consortium.

Kimbell, R. 2008. e-assessment in project e-scape. Design and Technology Education: an International Journal, 12.

Kozma, R. 2009. Transforming Education: Assessing and Teaching 21st Century Skills. Microsoft, Cisco, Intel.

Laurillard, D. (2012). Teaching as a design science. Building Pedagogical Patterns for Learning and Technology. New York:Routledge.

Levin, J. R., \& O'Donnell, A. M. (1999). What to do about educational research's credibility gaps? Issues in Education, 5(2), 177-229. 
Lewin, C. \& Luckin, R. 2010. Technology to support parental engagement in elementary education: Lessons learned from the UK. Computers \& education, 54, 749-758.

Luckin, R. 2010. Re-designing Learning Contexts: Technology-rich, learner-centred ecologies, London, Routledge.

Luckin, R., Logan, K., Clark, W., Graber, R., Oliver, M. \& Mee, A. 2008. KS3 and KS4 learners' use of Web 2.0 technologies in and out of school - Summary. Coventry: Becta.

Lytle, S. L. \& Cochran-Smith, M. 1994. Inquiry, knowledge, and practice. In: Hollingsworth, S. \& Sockett, H. (eds.) Teacher research and educational reform. Chicago: IL: University of Chicago Press.

Naudé, K.A., Greyling, J.H., \& Vogts, D. Marking student programs using graph similarity,. (2010) Computers \& Education, 54(2), 545-561.

O'Connell Rust, F. 2009. Teacher Research and the Problem of Practice. Teachers College Record, 111, 1882-1893.

OECD 2005. Formative Assessment: Improving Learning in Secondary Classrooms. Policy Briefs. Paris: OECD.

OECD 2010a. Are the New Millennium Learners Making the Grade? Technology Use and Educational Performance in PISA 2006. Paris: OECD/CERI.

OECD 2010b. Assessing the effects of ICT in education. In: SCHEUERMANN, F. \& PEDRÓ, F. (eds.). Paris: JRC, OECD.

P21-SKILLS 2007. 21st Century Skills Assessment. Washington DC: Partnership for 21st Century Skills.

Pachler, N., Mellar, H., Daly, C., Mor, Y. \& William, D. 2009. Scoping a vision for formative e-assessment. London: WLE Centre, Institute of Education.

Pedro, F. 2009. Is Technology Use Related To Educational Performance? Evidence From PISA. Paris: OECD/CERI.

Pedro, F. 2010. Inspired by Technology, Driven by Pedagogy: A systemic approach to technology-based school innovations. Paris: OECD/CERI.

Rich, P. \& Hannafin, M. 2008. Capturing and assessing evidence of student teacher inquiry: A case study. Teaching and Teacher Education, 24, 1426-1440.

Ripley, M. (2007) 'E-assessment - an update on research, policy and practice.' Bristol: Futurelab.

Ritchie, G. V. 2006. Teacher research as a habit of mind. PhD, George Mason University.

Sainsbury, M. E-assessment for schools: from innovation to integration. Association for Educational Assessment - Europe, 2009 Malta. National Foundation for Educational Research.

Shurville, S., Browne, T. \& Luckin R. 2007. Initiating e-learning by stealth, participation and consultation in a late majority institution. International Journal of Organisational Transformation and Social Change, 3, 317-332.

SQA (2007) 'E-assessment: Guide to effective practice.' Glasgow: Scottish Qualifications Authority.

Underwood, J., Luckin, R., Smith, H., Walker, K., Rowland, D., Fitzpatrick, G., Good, J. \& Benford, S. 2009. Reflections on Participatory Science for TELSci2. 0. telearnnoekaleidoscopeorg, 2, 197-314.

Wang, T-H. (2010) Web-based dynamic assessment: Taking assessment as teaching and learning strategy for improving students' e-Learning effectiveness. Computers \& Education, 54(4), 1157-1166. 
Webb, M. 2010. Beginning teacher education and collaborative formative e-assessment. Assessment \& Evaluation in Higher Education, 35, 597-618.

Winkley, J. 2010. E-assessment and innovation. Emerging Technologies. Coventry: Becta.

Wishart, J., \& Triggs, P. (2010) MuseumScouts: Exploring how schools, museums and interactive technologies can work together to support learning. Computers \& Education, 54(3), 669-678.

Zapata-Rivera, D., Hansen, E., Shute, V., Underwood, J. \& Bauer, M. 2007. Evidencebased approach to interacting with open student models. International Journal of Artificial Intelligence in Education, 17, 273-303.

Zeichner, K. M. 2003. Teacher research as professional development for P-12 educators in the USA. Educational Action Research, 11, 301-325. 


\section{TABLES}

\begin{tabular}{|c|c|c|c|}
\hline $\begin{array}{l}\text { Study } \\
\text { Characteristics }\end{array}$ & $\begin{array}{l}\text { Study } 1 \\
\text { (Barab et al., 2003) }\end{array}$ & $\begin{array}{l}\text { Study } 2 \\
\text { (Dawson, 2007) }\end{array}$ & $\begin{array}{l}\text { Study } \mathbf{3} \\
\text { (Rich and Hannafin, 2008) }\end{array}$ \\
\hline Relationships & $\begin{array}{l}\text { Teachers/Mentors } \\
\text { Researchers } \\
\text { Designers (Tools) }\end{array}$ & $\begin{array}{l}\text { Teachers/Mentors } \\
\text { Researchers }\end{array}$ & $\begin{array}{l}\text { Teachers/Mentors } \\
\text { Researchers } \\
\text { Designers (Tools) }\end{array}$ \\
\hline $\begin{array}{l}\text { Tool Design } \\
\text { Approach }\end{array}$ & $\begin{array}{l}\text { Participatory Co-Design } \\
\text { Researcher-led } \\
\text { Focus on tool/users } \\
\end{array}$ & $\begin{array}{l}\text { Readily Available Tools } \\
\text { Teacher selected } \\
\text { Focus on inquiry method }\end{array}$ & $\begin{array}{l}\text { Not specified } \\
\text { Researcher selected } \\
\text { Focus on tool/inquiry method }\end{array}$ \\
\hline $\begin{array}{l}\text { Tool } \\
\text { Developed }\end{array}$ & Yes (Website) & No (Ad hoc selection) & Yes (Video Analysis Tool) \\
\hline $\begin{array}{l}\text { Inquiry } \\
\text { Method Given }\end{array}$ & No & Yes & Yes \\
\hline $\begin{array}{l}\text { Area of } \\
\text { Inquiry (AoI) }\end{array}$ & Maths/Science & Technology & Assessment \\
\hline AoI chosen by & Academic Researchers & Academic Researchers & Teacher Educators \\
\hline $\begin{array}{l}\text { Sub-AoI } \\
\text { chosen by }\end{array}$ & Teachers & Teachers & Teachers \\
\hline Study Purpose & $\begin{array}{l}\text { Improve Class Practice } \\
\text { Teacher Development } \\
\text { Promote Inquiry } \\
\text { Learning } \\
\text { Develop Inquiry Tools } \\
\end{array}$ & $\begin{array}{l}\text { Improve Class Practice } \\
\text { Teacher Development } \\
\text { Develop Inquiry Methods }\end{array}$ & $\begin{array}{l}\text { Improve Class Practice } \\
\text { Teacher Development } \\
\text { Develop Inquiry Methods } \\
\text { Develop Inquiry Tool }\end{array}$ \\
\hline $\begin{array}{l}\text { Interaction } \\
\text { Type }\end{array}$ & $\begin{array}{l}\text { Communities of Practice } \\
\text { Collaborative Inquirers } \\
\text { Large and small scale } \\
\text { Peer education (informal) }\end{array}$ & $\begin{array}{l}\text { Collaborative Inquirers } \\
\text { Small scale } \\
\text { Teacher education (formal) }\end{array}$ & $\begin{array}{l}\text { Collaborative Inquirers } \\
\text { Small scale } \\
\text { Teacher education (formal) }\end{array}$ \\
\hline $\begin{array}{l}\text { Study } \\
\text { Approach }\end{array}$ & $\begin{array}{l}\text { Design-led (Tool) } \\
\text { Researcher-led (CoP) } \\
\text { Teacher-led (Inquiry) }\end{array}$ & $\begin{array}{l}\text { Researcher-led (Theory) } \\
\text { Teacher-led (Practice) } \\
\text { Both focused on Inquiry }\end{array}$ & $\begin{array}{l}\text { Researcher-led (Theory) } \\
\text { Teacher-led (Practice) } \\
\text { Both focused on Inquiry }\end{array}$ \\
\hline $\begin{array}{l}\text { Inquiry } \\
\text { Method }\end{array}$ & Not defined/prescribed & Defined/guided (Textbook) & Defined/guided (Trigger/Lens) \\
\hline Study Type & $\begin{array}{l}\text { Meta-study (R) / study } \\
\text { (T) }\end{array}$ & Meta-study (R) / study (T) & Meta-study (R) / study (T) \\
\hline $\begin{array}{l}\text { Key } \\
\text { Contribution }\end{array}$ & $\begin{array}{l}\text { Participatory Design } \\
\text { Collaborative Practice } \\
\text { and Communication } \\
\text { Teacher Development }\end{array}$ & $\begin{array}{l}\text { Inquiry Method } \\
\text { Teacher motivations } \\
\text { Framing an Inquiry } \\
\text { Question } \\
\text { Technology and Learning } \\
\end{array}$ & $\begin{array}{l}\text { Inquiry Method } \\
\text { Inquiry Tool and EBDS } \\
\text { Trigger/Lens Approach } \\
\text { Assessment Focus }\end{array}$ \\
\hline $\begin{array}{l}\text { Inquiry } \\
\text { Method }\end{array}$ & $\begin{array}{l}\text { Inquiry Lab (CPD } \\
\text { focused) } \\
\text { Inquiry Circles (Sharing) } \\
\text { Inquiry Classroom } \\
\text { (View) } \\
\text { My Desk (Teacher Folio) } \\
\text { ILF Lounge (Discuss) } \\
\text { ILF Library (Resources) } \\
\text { ILF News (Updates) } \\
\text { ILF Office (Information) }\end{array}$ & $\begin{array}{l}\text { Develop a 'burning } \\
\text { question' } \\
\text { Identify passions (framing) } \\
\text { Generate an inquiry plan } \\
\text { Collect and analyse data } \\
\text { Take action/implement } \\
\text { results } \\
\text { Share findings } \\
\text { Iterative process }\end{array}$ & $\begin{array}{l}\text { Establishing a trigger } \\
\text { Choosing a lens } \\
\text { Planning for/collecting data } \\
\text { Analysing data/practice } \\
\text { Changing practice } \\
\text { Sharing findings } \\
\text { Iterative process }\end{array}$ \\
\hline Issues Arising & $\begin{array}{l}\text { Control of design } \\
\text { Definition of terms } \\
\text { Insider/outsider gap in } \\
\text { knowledge and } \\
\text { understanding }\end{array}$ & $\begin{array}{l}\text { Guidance/support } \\
\text { Skills v pedagogy } \\
\text { Technical issues/support } \\
\text { Time/workload }\end{array}$ & $\begin{array}{l}\text { Guidance/support } \\
\text { Abandoning tool support for } \mathrm{f} 2 \mathrm{f} \\
\text { interaction } \\
\text { Motivation: time/workload } \\
\text { Single evidence source }\end{array}$ \\
\hline
\end{tabular}

Table 1: cross-case review of approaches to, and characteristics of, teacher inquiry research 


\begin{tabular}{|c|c|c|}
\hline Teacher Inquiry (TI) & $\begin{array}{l}\text { Teacher Design Research } \\
\text { (TDR) }\end{array}$ & $\begin{array}{l}\text { Teacher Inquiry into Students' } \\
\text { Learning (TISL) }\end{array}$ \\
\hline $\begin{array}{l}\text { Establishing a trigger question } \\
\text { Brainstorming 'passions' } \\
\text { Choosing a lens }\end{array}$ & $\begin{array}{l}\text { Collaborative needs analysis } \\
\text { Explicit articulation of current } \\
\text { beliefs/practices } \\
\text { Select an area of study } \\
\text { Align to state and national } \\
\text { standards }\end{array}$ & $\begin{array}{l}\text { Research orientation (methods and } \\
\text { tools) } \\
\text { Collaborative needs analysis/contextual } \\
\text { analysis } \\
\text { Establishing a trigger } \\
\text { Articulation of current beliefs/practices } \\
\text { Choosing an assessment-oriented lens } \\
\text { Framing purpose(s) }\end{array}$ \\
\hline Guidance/Support/Dialogue & Guidance/Support/Dialogue & Guidance/Support/Dialogue \\
\hline $\begin{array}{l}\text { Developing a plan of action } \\
\text { Data collection } \\
\text { Data analysis } \\
\text { Data interpretation } \\
\text { (Iterate and refine) }\end{array}$ & $\begin{array}{l}\text { Data collection (literature } \\
\text { reviews, learning data sets - } \\
\text { students, colleagues, experts) } \\
\text { Data and context analysis } \\
\text { Data-driven decision-making } \\
\text { Data interpretation }\end{array}$ & $\begin{array}{l}\text { Developing a plan of action } \\
\text { Data-driven decision-making } \\
\text { Data collection/capture } \\
\text { Data visualisation } \\
\text { Data and context analysis } \\
\text { Data interpretation (filters, influences, } \\
\text { relations) } \\
\text { Data validation }\end{array}$ \\
\hline $\begin{array}{l}\text { Enacting change } \\
\text { (Iterate and refine) }\end{array}$ & $\begin{array}{l}\text { Conceptual design and } \\
\text { prototyping } \\
\text { Cycles of evaluation and analysis } \\
\text { Emergent process model }\end{array}$ & $\begin{array}{l}\text { Iterative design cycle } \\
\text { Technology awareness } \\
\text { Conceptual design/protoptyping } \\
\text { Enacting change }\end{array}$ \\
\hline $\begin{array}{l}\text { Sharing findings } \\
\text { (Iterate and refine) }\end{array}$ & $\begin{array}{l}\text { Presentation of conceptual design } \\
\text { and prototyping to others }\end{array}$ & Sharing results \\
\hline Teacher-centred & Teacher-centred & Teacher, learner and school-centred \\
\hline $\begin{array}{l}\text { Continuity of change in action } \\
\text { Sustained professional growth } \\
\text { Developing an Inquiry Stance }\end{array}$ & $\begin{array}{l}\text { Continuity of change in action } \\
\text { Sustained practice-based } \\
\text { professional development } \\
\text { Cycles of research }\end{array}$ & $\begin{array}{l}\text { Sustained practice-based professional } \\
\text { development } \\
\text { Real-time adaptive teaching and } \\
\text { learning } \\
\text { Continuous diffusion of innovation } \\
\text { Informed participation in research } \\
\text { community }\end{array}$ \\
\hline $\begin{array}{l}\text { FOCUS: } \\
\text { Action } \\
\text { Professional development } \\
\text { Learner improvement } \\
\text { School improvement }\end{array}$ & $\begin{array}{l}\text { FOCUS: } \\
\text { Design } \\
\text { Professional development } \\
\text { Learner development }\end{array}$ & $\begin{array}{l}\text { FOCUS: } \\
\text { Assessment } \\
\text { Professional development } \\
\text { School improvement } \\
\text { Assessment literacy (with certification) } \\
\text { Summative, evaluative, formative } \\
\text { Formative e-assessment } \\
\end{array}$ \\
\hline $\begin{array}{l}\text { GOAL: Teachers as innovators, } \\
\text { making changes to practice, } \\
\text { informing wider educational } \\
\text { agendas, shift in teacher beliefs } \\
\text { about innovation and practice }\end{array}$ & $\begin{array}{l}\text { GOAL: Teacher as innovators, } \\
\text { adaptive teaching, participants in } \\
\text { multiple design cycles, shift in } \\
\text { teacher beliefs about innovation } \\
\text { and practice }\end{array}$ & $\begin{array}{l}\text { GOAL: Teacher as professional } \\
\text { practitioners, able to make informed } \\
\text { changes to their practice, through an } \\
\text { enhanced understanding of technology- } \\
\text { rich learning contexts and formative e- } \\
\text { assessment. }\end{array}$ \\
\hline
\end{tabular}

Table 2: teacher inquiry into students' learning: from action research to formative eassessment in technology-rich learning contexts 
